\title{
Repensando o Ensino dos Direitos Humanos na Academia Jurídica: 0 Resgate das Contribuições Coloniais e Contemporâneas da América Latina na Fundamentação de um Novo Discurso
}

\author{
Rethinking the Human Rights Teachings in the Academy of Law: the Recovery \\ of Latin America's Colonial and Contemporary Contributions in Justification of \\ a New Speech
}

\section{WILSON ENGELMANN}

Doutor e Mestre em Direito Público pelo Programa de Pós-Graduação em Direito (Mestrado e Doutorado) da Universidade do Vale do Rio dos Sinos - Unisinos/RS/Brasil, Professor deste mesmo Programa das atividades: "Transformações Jurídicas das Relações Privadas" (Mestrado) e "Os Desafios das Transformações Contemporâneas do Direito Privado" (Doutorado), Coordenador Executivo do Mestrado Profissional em Direito da Empresa e dos Negócios da Unisinos, Líder do Grupo de Pesquisa JUSNANO (CNPq), Bolsista de Produtividade em Pesquisa do CNPq.

\section{RAQUEL VON HOHENDORFF}

Doutoranda e Mestre em Direito Público pelo Programa de Pós-Graduação em Direito (Mestrado e Doutorado) da Universidade do Vale do Rio dos Sinos - Unisinos/RS/Brasil, Bolsista Capes, Membro do Grupo de Pesquisa JUSNANO (CNPq), Advogada.

Data da Submissão: 18.09 .2016

Data da Decisão Editorial: 12.10 .2016

Data da Comunicação do Autor: 12.10.2016

RESUMO: Este artigo tem por objetivo analisar o ensino dos direitos humanos nos cursos de Direito brasileiros, demonstrando a necessidade de resgatar as contribuições latino-americanas na fundamentação do estudo destes direitos. Identifica-se que o ensino dogmático e fragmentado atual falha quanto à formação de cidadãos aptos a lidar com a realidade dos direitos humanos. A falácia do discurso dominante hegemônico europeu dos direitos humanos acaba promovendo o encobrimento das especificidades do tema na América Latina e o seu papel em relação à promoção e proteção dos direitos humanos. Isso pode ser considerada uma das justificativas da falta de interesse no 
aprofundamento destes estudos. Assim, necessário se faz o resgate das contribuições latino-americanas para a fundamentação dos direitos humanos. A partir da revisão da bibliografia e utilização da análise do conteúdo das fontes consultadas, se sustentará metodologicamente este artigo. A profundidade deste resgate deve retornar aos tempos da colonização, buscando os debates sobre a dignidade indígena e chegar até o século passado, com as contribuições contemporâneas dos países latino-americanos nas declarações de direitos humanos, demonstrando, assim, o papel precursor e atuante destas nações na construção de um discurso não individualista de direitos humanos. Como conclusão, se destaca a fundamentalidade do tema dos direitos humanos na construção do conhecimento jurídico conectado com a realidade brasileira e latino-americana, em que a atuação dos egressos dos cursos jurídicos desenvolverá a sua atividade profissional. 0 conhecimento técnico deverá ser enucleado nos pressupostos ético-axiológicos inseridos nos elementos estruturantes dos denominados direitos (dos) humanos.

PALAVRAS-CHAVE: Ensino jurídico; direitos humanos; colonização; encobrimento; contribuições latino-americanas.

ABSTRACT: This article's objective is to analyze the teachings of human rights in the Brazilian Law schools, indicating the necessity to recover the Latin American contributions in the justification of those rights studies. The current dogmatic and fragmented teaching is failing to contribute with the formation of citizens that must deal with the reality of human rights. The fallacy of the European hegemonic dominant speech of human rights upholds a cover up of the peculiarities of the subject in Latin America, as well as its role on promoting and protecting these rights. This misconception can be considered one of the reasons in the lack of interest in deepen the studies. Therefore, there is a necessity to restore the past contributions. The methodology to support this article is based on bibliographic review and content analysis of consulted sources. The depth of this recovery must go as far as the colonization, seeking to debate about the indigenous dignity and return to the past century, and with the contemporary contribution of the Latin American countries in the declaration of human rights, demonstrate the precursor role of those nations in the construction of the non-individual speech of human rights. The findings highlight the topic of fundamental human rights in order to build legal knowledge connected with the Brazilian and Latin American realities, where the former law students will develop their legal professional activities. The technical knowledge will be centered in the ethical-axiological assumption inserted in the structural elements denominated the rights (of) humans.

KEYWORDS: Legal education; human rights; Colonization; cover up; latin american contributions.

SUMÁRIO: Introdução; 10 ensino de direitos humanos na academia jurídica brasileira; 2 A falácia do discurso dominante: 0 encobrimento e resgate da América Latina na construção do discurso dos direitos humanos; 3 Contribuições latino-americanas para promoção e proteção dos direitos humanos no âmbito internacional; Considerações finais; Referências.

\section{INTRODUÇÃO}

Atualmente, existem inúmeros fatores que ameaçam os direitos humanos, como a incapacidade do Governo no controle adequado de seus agentes, o crescimento da criminalidade comum, o forte preconceito cultural existente, a falta de equidade na aplicação das leis, a pobreza e a mar- 
ginalidade disseminadas em várias parcelas da população e as deficiências dos sistemas educacionais' ${ }^{1}$.

Assim, em um país como o Brasil, onde diariamente ocorrem inúmeros casos de violação dos direitos humanos, é necessário rediscutir o papel do ensino de direitos humanos, em todos os níveis educacionais, especialmente no ensino jurídico.

Causou estranheza e inquietação, quem sabe indignação, a um dos autores ter acesso a certas informações históricas sobre o papel precursor e inovador latino-americano na internacionalização dos direitos humanos apenas em uma disciplina de pós-graduação, mesmo tendo cursado a graduação em direito em uma universidade que disponibiliza a disciplina de direitos humanos em seu currículo como obrigatória. Desse modo, surgiu a ideia de se aprofundar no tema, questionando alguns aspectos da educação em direitos humanos no ensino jurídico e relacionando-os com o encobrimento das contribuições latino-americanas para a promoção e proteção dos direitos humanos.

A primeira parte do artigo tratará da atual realidade do ensino de direitos humanos no Brasil, relacionando-a com o disposto na Declaração Universal dos Direitos Humanos, ou seja, a implementação dos direitos humanos depende de uma intervenção educativa. Para tanto, será abordado o Plano Nacional de Ensino de Direitos Humanos, criado em 2007, suas diretrizes e metas, bem como suas falhas.

Ainda na parte inicial será discutida a educação em direitos humanos no ensino jurídico brasileiro, apresentando-se as diretrizes curriculares que não contem direitos humanos como disciplina do eixo obrigatório, a discussão sobre o império da dogmática e da fragmentação do ensino, bem como as possibilidades de ensinar direitos humanos de forma transversal, ao longo do curso, para que efetivamente sejam formados cidadãos, aptos ao entendimento dos direitos humanos e capazes de promover mudanças na sociedade.

Em um segundo momento, será tratada, inicialmente, a falácia do discurso dominante hegemônico europeu dos direitos humanos, desconstruindo o encobrimento da América Latina em seu papel em relação aos direitos humanos.

1 ALVES, José Augusto Lindgren. Os direitos humanos como tema g/obal. 2. ed. São Paulo: Perspectiva, 2003. p. 189. 
Em seguida, será abordado o resgate deste papel da América Latina, com as contribuições de Bartolomé de Las Casas e Francisco de Vitória, em contraponto ao discurso em defesa da colonização de Ginés Sepúlveda. Estas discussões acerca dos direitos indígenas na América colonizada foram as primeiras contribuições deste continente para com a fundamentação de um discurso de direitos humanos diferente do hegemônico europeu, valorizando a diversidade e o respeito pela alteridade do outro.

$\mathrm{Na}$ parte final, serão trazidos dados históricos referentes ao papel latino-americano na promoção e proteção dos direitos humanos no âmbito internacional. A Constituição mexicana de 1917, a participação ativa das nações latinas para que a Carta da ONU contivesse elementos relativos aos direitos humanos, a elaboração da Declaração Americana dos Direitos e Deveres do Homem da OEA, que precedeu em meses a Declaração Universal, e as importantes contribuições na construção da Declaração Universal dos Direitos Humanos, da ONU, que foi criada com base no projeto apresentado pelo Panamá, serão aspectos abordados e contextualizados nesta etapa do trabalho.

Assim, considerando a importância do tema, a abordagem deste trabalho buscará expor algumas das deficiências do ensino dos direitos humanos em nível de graduação de direito no Brasil, questionando o porquê da manutenção do discurso dominante europeu como base dos direitos humanos, enquanto vivemos em um continente que possui uma longa tradição histórica na defesa destes direitos.

\section{ENSINO DE DIREITOS HUMANOS NA ACADEMIA JURÍDICA BRASILEIRA}

Educação não transforma o mundo. Educação muda as pessoas. Pessoas transformam o mundo.

(Paulo Freire)

A realidade atual da educação em direitos humanos no ensino jurídico brasileiro, apesar da existência, desde 2007, do Plano nacional de Ensino de Direitos Humanos (PNEDH), não pode ser caracterizada como desejável ou adequada. Ainda existem inúmeras falhas a serem corrigidas e desafios a serem enfrentados para que se atinja um nível ao menos satisfatório. Existe um elo perverso de ligação entre o desconhecimento e a efetividade dos direitos humanos, e a reversão deste quadro passa pela atuação de muitos atores, principalmente do Estado, mas também dos cidadãos, por meio da 
atuação em organizações não governamentais, universidades, empresas, etc. $^{2}$

O Programa Nacional de Direitos Humanos, em sua terceira versão, lançada em 2010, tem os seguintes eixos orientadores: 1. Interação Democrática entre Estado e Sociedade Civil; 2. Desenvolvimento e Direitos Humanos; 3. Universalizar Direitos em um Contexto de Desigualdades; 4. Segurança Pública, Acesso à Justiça e Combate à Violência; 5. Educação e Cultura em Direito Humanos; e 6. Direito à Memória e Verdade 3 .

Se percebe a importância dos conhecimentos relativos aos direitos humanos na estruturação do conhecimento jurídico, pois eles serão responsáveis pela viabilização de aproximações e relacionamentos entre os conhecimentos técnicos específicos.

Nesse sentido, a Declaração Universal dos Direitos Humanos, de 1948, em seu preâmbulo, dispõe que a promoção do respeito aos direitos e às liberdades nela contidos precisa ocorrer por intermédio do ensino e da educação, expondo a importância que o ensino de direitos humanos tem na viabilização de sua concretização. Ainda, o art. 26 dispõe que "[a] instrução será orientada no sentido pleno do desenvolvimento da personalidade humana e do fortalecimento do respeito pelos direitos do homem e pelas liberdades fundamentais" ${ }^{4}$.

Luis Alberto Warat indica que a aprovação da Declaração Universal dos Direitos Humanos pela Assembleia Geral das Nações Unidas já produziu uma "resposta educativa", seja porque acolheu expressamente o direito à educação em seu bojo, seja porque estabeleceu, em seu preâmbulo, que a implementação dos direitos humanos depende de uma "intervenção educativa". Ainda, Warat, quanto ao papel da educação em relação aos direitos humanos, menciona que a educação é necessária para a compreensão, divulgação e conscientização destes direitos, e a ela deve ser dado o máximo protagonismo, pois sem educação não se realizam os direitos humanos ${ }^{5}$.

2 MORAIS, José Luís Bolzan de; VIEIRA, Gustavo Oliveira. A necessidade da voz da sociedade civil organizada na concretização dos direitos humanos. In: GONÇALVES, Claudia Maria da Costa (Coord.). Direitos humanos - Vozes e silêncio. Curitiba: Juruá, 2011. p. 80.

3 BRASIL. PNDH-3 reúne políticas sobre direitos humanos. Disponível em: <http://www.brasil.gov.br/ cidadania-e-justica/2012/04/PNDH-3-reune-politicas-sobre-direitos-humanos>. Acesso em: 10 jul. 2016.

4 COMPARATO, Fábio Konder. A afirmação histórica dos direitos humanos. 5. ed. rev. e atual. São Paulo: Saraiva, 2007. p. 251.

5 WARAT, Luis Alberto. Direitos humanos: subjetividade e práticas pedagógicas. In: SOUSA JÚNIOR, José Geraldo et al. (Org.). Educando para os direitos humanos: pautas pedagógicas para a cidadania na universidade. Porto Alegre: Síntese, 2004. p. 71. 
Apesar de a Declaração Universal dos Direitos Humanos ter mais de 60 anos, inúmeros profissionais atuantes na área do Direito não possuem uma cultura em direitos humanos, sendo isto um grave reflexo da formação positivista e normativista que perdura ao longo da história do ensino jurídico brasileiro. É fácil perceber que o ensino de Direito no país tem costumeiramente conservado o dogmatismo ainda dominante no pensamento jurídico. A ideia principal segue sendo de que o ensino é um simples processo de transmissão de conhecimentos, onde cabe ao professor ensinar (de qualquer modo) e, ao aluno, apenas aprender (sem precisar, para tanto, pensar). Desse modo, ocorre a falha abismal do processo de ensino frente a sua meta primordial (desenvolver o senso crítico, o pensar autônomo), que apenas pode se concretizar por meio da livre tomada de consciência dos problemas do homem e do mundo, e do real e efetivo engajamento para solucionar estes problemas $^{6}$. Neste sentido, Boaventura de Sousa Santos esclarece:

O paradigma jurídico-dogmático que domina o ensino nas faculdades de direito não tem conseguido ver que na sociedade circulam várias formas de poder, de direito e de conhecimentos que vão muito além do que cabe nos seus postulados. Com a tentativa de eliminação de qualquer elemento extra-normativo, as faculdades de direito acabaram criando uma cultura de extrema indiferença ou exterioridade do direito diante das mudanças experimentadas pela sociedade. Enquanto locais de circulação dos postulados da dogmática jurídica, têm estado distantes das preocupações sociais e têm servido, em regra, para a formação de profissionais sem um maior comprometimento com os problemas sociais. ${ }^{7}$

A formação acadêmica jurídica brasileira, ainda hoje, em muitos casos, consiste em repetir lições de manuais, copiar ementas de jurisprudência (sem análise do caso concreto), reproduzir a decisão judicial como verdade absoluta e copiar posições de códigos comentados. Desse modo, nosso ensino jurídico anda em sentido inverso da fase cultural pós-moderna, uma vez que é "ensinado" um conhecimento baseado no positivismo exegético-normativista, sem qualquer profundidade ou seriedade maior, em vez de formar profissionais jurídicos críticos, reflexivos e preocupados com a função social do Direito ${ }^{8}$.

6 MARQUES NETO, Agostinho Ramalho. Introdução ao estudo do direito: conceito, objeto, método. 2. ed. Rio de Janeiro: Forense, 2001. p. 209.

7 SANTOS, Boaventura de Sousa. Para uma revolução democrática da justiça. 2. ed. São Paulo: Cortez, v. 134, 2008. p. 71.

8 MACEDO, Elaine Harzheim; MACEDO, Fernanda dos Santos. O ensino jurídico no sistema globalizado: repensando a educação e a pesquisa. XXI Encontro Nacional do Conpedi, Uberlândia, 2012. Disponível em: <http://www. publicadireito.com.br/artigos/?cod=feab05aa91085b7a >. Acesso em: 10 jul. 2016. 
Apesar disso, resta bem claro que o tema dos direitos humanos não está expressamente consagrado como um conhecimento a ser desenvolvido na graduação em Direito, pois as Diretrizes Curriculares Nacionais para o Curso de Graduação em Direito $^{9}$ não trazem essa sinalização. Segundo a redação do art. $3^{\circ}$ das Diretrizes Curriculares,

o curso de graduação em Direito deverá assegurar, no perfil do graduando, sólida formação geral, humanística e axiológica, capacidade de análise, domínio de conceitos e da terminologia jurídica, adequada argumentação, interpretação e valorização dos fenômenos jurídicos e sociais, aliada a uma postura reflexiva e de visão crítica que fomente a capacidade e a aptidão para a aprendizagem autônoma e dinâmica, indispensável ao exercício da Ciência do Direito,da prestação da justiça e do desenvolvimento da cidadania.

Aqui se percebe clara abertura para a inserção do tema dos direitos humanos.

A atual incapacidade das escolas jurídicas em formar profissionais aptos a atuar em uma sociedade que vive com constantes transformações é pública e notória, estando associada ao modelo de ensino adotado, pautado na exigência de memorização de conteúdos, fragmentação dos saberes, especialização excessiva e em uma pedagogia centrada exclusivamente na figura do professor. Portanto, para que se possa efetivamente ensinar direitos humanos no ensino jurídico, é preciso que os projetos pedagógicos existentes hoje sejam alterados, passando a considerar menos a dogmática e mais a realidade, isto é, para que os direitos humanos posam ser legitimados e concretizados, é necessária uma educação preocupada com a sua origem histórica, com seus fundamentos e sua aplicação na realidade prática. Conforme Warat,

as articulações entre educação e direitos humanos devem supor um projeto pedagógico integrado que incite a viver e desfrutar dos direitos humanos: que permita a compreensão e o aprendizado do valor existencial, que implica para os excluídos e os esquecidos, o exercício das práticas reivindicatórias de seus direitos de alteridade (as pessoas precisam aprender a exercer o valor da vida através da realização dos direitos humanos: a biopolítica resistida e contestada por uma concepção e uma prática vitalista dos direitos humanos); e, fundamentalmente, que permita fomentar um estado de opinião que a leve a pensar que qualquer violação dos direitos humanos em qualquer lugar do mundo não nos pode deixar indiferentes, sendo de todos a responsabilidade de evitá-las. ${ }^{10}$

9 BRASIL. Diretrizes Curriculares Nacionais para o Curso de Graduação em Direito. Disponível em: <http:// portal.mec.gov.br/cne/arquivos/pdf/rces09_04.pdf>. Acesso em: 10 jul. 2016.

10 Warat, op. cit., p. 72 
Uma prática do direito descompromissada com suas consequências sociais é resultado do atual ensino jurídico, em que não importam as pessoas que estão por detrás dos autos, nem, tampouco, a possibilidade de efetividade da decisão. E é neste contexto que o ensino de direitos humanos, nas faculdades de Direito do Brasil, acaba limitando-se, por exemplo, ao estudo da extensão e aplicação dos tratados internacionais, como eles ingressam no ordenamento pátrio, mas sem considerar que os direitos humanos estão presentes - ainda que violados - nas questões corriqueiras do nosso dia a $\operatorname{dia}^{11}$.

Em relação ao ensino dos direitos humanos nas escolas de Direito ${ }^{12}$, cabe, inicialmente, mencionar alguns aspectos do Plano Nacional de Ensino de Direitos Humanos (PNEDH), considerando que somente após quase sessenta anos da aprovação da Declaração Universal dos Direitos Humanos ocorreu no país um movimento para institucionalizar uma política pública de educação em direitos humanos no Brasil. Este movimento concretizou-se com o PNEDH ${ }^{13}$, que consiste em uma política pública voltada especificamente para lidar com os desafios provenientes da proposta de se promover uma cultura de direitos humanos no País.

A elaboração do PNEDH se iniciou em 2003, com a criação do Comitê Nacional de Educação em Direitos Humanos, composto por especialistas em direitos humanos, representantes da sociedade civil, de instituições públicas e privadas, além de representantes de organismos internacionais, que trabalharam na elaboração da primeira versão do plano. Já, no decorrer de 2004 e 2005, essa primeira versão foi divulgada e debatida em diversos

11 SENA, Jaqueline Santa Brígida. Ética da alteridade e direitos humanos: uma discussão necessária à formação jurídica contemporânea. In: NALINI, José Renato; CARLINBI, Angélica (Coord.). Direitos humanos e formação jurídica. Rio de Janeiro: Forense, 2010. p. 16.

12 O tema dos direitos humanos ainda é turvado por um véu de desconfianças e preconceitos. Fala-se pouco (e mal) dos direitos humanos. E o ensino jurídico, calcado na ortodoxia epistemológica, ainda procura compreender o universo das relações sociais por meio de fragmentos de saberes surdos-mudos, cuja pretensão repousa na autossuficiência arrogante de seus conteúdos. Inclusive confinando (a disciplina) direitos humanos em um espaço próprio, isolado, muitas vezes destinado à leitura em monocórdio dos principais diplomas legais na ordem internacional e de modorrenta doutrina (LEVY, Wilson. A emergência da pedagogia do novo e de uma teoria emancipatória do ensino do direito. In: NALINI, José Renato; CARLINBI, Angélica (Coord.). Direitos humanos e formação jurídica. Rio de Janeiro: Forense, 2010. p. 37.

13 Quanto à origem do PNEDH, cabe mencionar: o Plano Nacional de Educação em Direitos Humanos (PNEDH) é fruto do compromisso do Estado com a concretização dos direitos humanos e de uma construção histórica da sociedade civil organizada. Ao mesmo tempo em que aprofunda questões do Programa Nacional de Direitos Humanos, o PNEDH incorpora aspectos dos principais documentos internacionais de direitos humanos dos quais o Brasil é signatário, agregando demandas antigas e contemporâneas de nossa sociedade pela efetivação da democracia, do desenvolvimento e da justiça social e pela construção de uma cultura de paz (BRASIL. Plano Nacional de Educação em Direitos Humanos: 2007, Comitê Nacional de Educação em Direitos Humanos. Brasília: Secretaria Especial de Direitos Humanos, Ministério da Educação, Ministério da Justiça, Unesco, 2006. Disponível em: <http://portal.mj.gov.br/sedh/edh/pnedhpor.pdf>. Acesso em: 10 jul. 2016. 
eventos, realizados em todo o País, e, em 2007, a última versão foi publicada, já com os resultados dos debates ${ }^{14}$.

De um modo geral, o PNEDH, em sua última versão, resultou na construção de uma política pública de educação orientada em dois sentidos: (i) na consolidação de um projeto de sociedade baseada nos princípios da democracia, cidadania e justiça social; (ii) no reforço da construção de uma cultura de direitos humanos, entendida como um processo a ser apreendido e vivenciado na perspectiva da cidadania ativa. $\mathrm{O}$ seu objetivo primordial é a difusão de uma cultura de direitos humanos, a ser realizada pela disseminação de valores solidários, cooperativos e de justiça social, que possam se traduzir no fortalecimento da sociedade civil, no sentido de que as conquistas reclamadas sejam efetivamente incorporadas nas políticas públicas $^{15}$.

O PNEDH pode ser considerado como uma resposta quanto ao direito à educação previsto já na Declaração Universal dos Direitos Humanos, em 1948. Mas, apesar de ter traçado objetivos, diretrizes e todos os demais termos constantes em todos os planos de políticas públicas, questiona-se acerca de sua real implementação. Apesar de o plano abordar as Instituições de Ensino Superior (IES) ${ }^{16}$, parece que estas não o conhecem. Mais ainda, em relação ao ensino jurídico, o desconhecimento parece ser gigantesco, tendo em vista que as diretrizes curriculares mínimas do curso de Direito ainda não foram modificadas após a criação e publicação do plano. Ainda hoje, em 2013, as diretrizes curriculares para o Direito ${ }^{17}$ são as mesmas de 2004, não incluindo a disciplina de direitos humanos como obrigatória. Assim, a pergunta que resta é: Será esta a forma de implantação do referido plano?

O próprio plano menciona a questão da possibilidade de ensino dos direitos humanos de modo transversal ${ }^{18}$, não apenas em uma única discipli-

14 Idem

15 Idem.

16 O plano assim dispõe: "A conquista do Estado Democrático delineou, para as Instituições de Ensino Superior (IES), a urgência em participar da construção de uma cultura de promoção, proteção, defesa e reparação dos direitos humanos, por meio de ações interdisciplinares". Posteriormente expõe os vários princípios a serem considerados: comprometimento com a democracia e a cidadania, igualdade, liberdade e justiça em suas ações, a difusão dos valores democráticos e republicanos, a formação de uma cultura baseada na universalidade, indivisibilidade e interdependência dos direitos humanos, como tema transversal e transdisciplinar. Posteriormente trata das ações programáticas para o alcance de suas metas, dentre "propor a temática da educação em direitos humanos para subsidiar as diretrizes curriculares das áreas de conhecimento das IES" e, ainda, "contribuir para a difusão de uma cultura de direitos humanos" (Idem).

17 BRASIL. Resolução CNE/CES no 9, de 29 de setembro de 2004. Disponível em: <http://portal.mec.gov.br/ cne/arquivos/pdf/rces09_04.pdf>. Acesso em: 10 jul. 2016.

18 No ensino, a educação em direitos humanos pode ser incluída por meio de diferentes modalidades, tais como disciplinas obrigatórias e optativas, linhas de pesquisa e áreas de concentração, transversalização no projeto político-pedagógico, entre outros (Idem). 
na; no entanto, sabe-se da enorme dificuldade dos docentes da área jurídica de trabalhar de modo transversal e interdisciplinar. Hoje, o ensino jurídico é ministrado de maneira compartimentada, com excesso de abstração e formalismo, à margem de qualquer interação com as necessidades reais da sociedade, sendo que o trabalho ocorre de forma disciplinar, concentrado em torno de determinado objeto de estudo, sem conexão e tampouco preocupação com outras áreas ou temas similares. Ainda quanto ao ensino fragmentado, Edgar Morin dispõe que fruto desta inteligência parcelada, compartimentada, mecanicista e reducionista ocorre como rompimento da complexidade do mundo em fragmentos disjuntivos, fracionando os problemas e separando o que está unido ${ }^{19}$. Aos estudantes foi ensinado apenas a separar, compartimentar, isolar e não unir os conhecimentos ${ }^{20}$.

Joaquim Herrera Flores propõe o uso, na prática pedagógica, do "diamante ético", por meio do qual se reproduz uma forma com múltiplas facetas da compreensão dos direitos humanos, reforçando, assim, a transversalidade deste tema, em todos os conteúdos estudados ${ }^{21}$. Diante da realidade exposta, na qual as diretrizes curriculares para o ensino superior de direito não exigem a obrigatoriedade da disciplina de direitos humanos (e, pasmem, pois mesmo diante da importância e imprescindibilidade do estudo dos direitos humanos para a formação de reais cidadãos, muitas universidades não dispõem da disciplina nem como obrigatória e tampouco como optativa), é necessário que os educadores do ensino jurídico tenham em mente a necessidade de ensinar direitos humanos, seja de modo disciplinar, interdisciplinar ou transversal.

É necessário sinalizar a todos os professores do ensino jurídico a possibilidade de ensinar e construir conhecimentos acerca de direitos humanos em todas as diferentes áreas e disciplinas do curso. Cabe um convite à reflexão para os juristas, professores e pesquisadores ${ }^{22}$ para que aceitem o desafio de incluir o estudo dos direitos humanos em todos os momentos, como

19 MORIN, Edgar. Os sete saberes necessários à educação do futuro. 8. ed. Trad. Catarina Eleonora F. da Silva e Jeanne Sawaya. São Paulo: Cortez; Brasília/DF: Unesco, 2003. p. 43.

20 COSTA, Bárbara Silva. A (in)suficiência do paradigma dogmático no modo de observar e ensinar o direito. Dissertação (Mestrado em Direito) - Programa de Pós-Graduação em Direito da Universidade do Vale do Rio dos Sinos. São Leopoldo/RS, 2007. p. 75.

21 FLORES, Joaquim Herrera. A (re)invenção dos direitos humanos. Trad. Carlos Roberto Diogo Garcia, Antonio Henrique Graciano Suxberger e Jefferson Aparecido Dias. Florianópolis: Fundação Boiteux, 2009. p. 123.

22 Conforme Herrera Flores: "Ponderar na escola, na aula universitária ou na sede dos movimentos e associações de defesa e promoção dos direitos quais foram os processos históricos e normativos que deram lugar a uma determinada configuração de direitos; analisar detidamente que tipo de relação social é que se estabelece e finalmente valorar a proximidade humana (vida, liberdade e igualdade) pode nos oferecer um marco pedagógico e prático que facilite entender os direitos em toda sua complexidade e na profundidade de sua natureza" (Flores, op. cit., p. 113). 
um prumo, balizador da construção do conhecimento nessa área ${ }^{23}$. Ainda, seria adequado elaborar um "modelo de educação em direitos humanos que respeite as visões de mundo e a alteridade dos educandos" 24 , formando-os como reais cidadãos, com participação efetiva na sociedade. Conforme Joaquim Herrera Flores, precisa-se resgatar o papel interpretativo dos direitos humanos a partir de uma estética da interatividade que conduza à formação de um "leitor/intérprete/ator implícito e interativo", sendo necessário que o conhecimento se oriente pelo conhecer/compreender/transformar ${ }^{25}$.

A educação em direitos humanos, como fundamento necessário para a plena cidadania, precisa estar presente em todos os níveis de ensino. Porque, conforme Ana Ferraz, "não há cidadão consciente onde não há o conhecimento, o exercício e o respeito dos direitos fundamentais da pessoa humana"26. No mesmo sentido, Paulo César Carbonari comenta que "a educação é, a um só tempo, um direito humano e também uma mediação histórica, institucional e subjetiva, para a efetivação do conjunto de direitos humanos" 27.

Associado a isso, percebe-se que a dificuldade de ensinar direitos humanos no Brasil, seja em uma disciplina única ou de modo transversal, está atrelada à dificuldade de fundamentar por meio de um argumento concreto o porquê de lutar pela preservação dos direitos humanos. A maioria das universidades, cujo currículo agrega o ensino de direito humanos, apresenta aos alunos um discurso de universalidade dos direitos humanos identificado como o universalismo dos povos europeus ${ }^{28}$, ou seja, um universalismo parcial e individualista, que desfavorece o interesse acadêmico sobre o tema.

23 NALINI, José Renato. Apresentação. In: NALINI, José Renato Nalini; CARLINI, Angélica (Coord.). Direitos humanos e formação jurídica. Rio de Janeiro: Forense, 2010. p. XV.

24 FREITAS, Ana Teresa Silva de. Ensino e legitimação dos direitos humanos. In: GONÇALVES, Claudia Maria da Costa (Coord.). Direitos humanos - Vozes e silêncio. Curitiba: Juruá: 2011. p. 152.

25 Flores, op. cit., p. 123.

26 FERRAZ, Anna Cândida da Cunha. Educação em direitos humanos: pressuposto para o exercício da cidadania. In: SILVEIRA, Vladimir Oliveira da; SANCHES, Samyra Haydêe Dal Farra Naspolini; COUTO, Mônica Bonetti (Org.). Educação jurídica. São Paulo: Saraiva, 2013. p. 99.

27 CARBONARI, P. C. Sujeito de direitos humanos: questões abertas e em construção. In: SILVEIRA, Rosa Maria Godoy et al. (Org.). Educação em direitos humanos: fundamentos teórico-metodológicos. 1. ed. João Pessoa: UFPB, 2007. p. 182.

28 O discurso europeu foi internalizado não apenas em relação aos direitos humanos, mas, sim, praticamente todo o "Direito" ensinado no Brasil remete ao Direito europeu. Neste sentido, Jorge L. Esquirol comenta: "More sharply focused, latin America's traditional program in Law - assimilating local societies to na idealized Europe - is strikingly unsatisfactory and counterproductive. Legalized assimilation aspires to a single and exclusive cultural form whilw reinforcing the legal system's calculed unresponsiveness to divergent identity formations. Difference is programmatically denied. Moreover, assimilation has not wholly succeeded on its own terms, in recreating Latin America as European. To the contrary, it has perpetuated the cultural divisiveness of colonial experience. Over time, it has contributed to insulating the legal system from transparent and robust engagement with the cultural commitments of Latin American peoples" (ESQUIROL, Jorge L. The fictions of Latin American law. Utah Law Review, Salt Lake City/USA, 425, 1997. p. 431. 
O discurso ensinado e apresentado na academia remete o início da filosofia dos direitos humanos às revoluções liberais francesas, desconsiderando as contribuições da América Latina na construção destes ideais. Assim, resgatar a importância do ensino dos direitos humanos implica o resgate do papel latino-americano na formação destes direitos.

Desse modo, a construção de uma política pública de ensino em direitos humanos precisa retomar a importância das contribuições oriundas de discussões promovidas na América Latina para a construção de um novo discurso de direitos humanos, que seja mais inclusivo e coletivo, do que isolador e individualista. Esse processo passa pela retomada das discussões coloniais que defendiam o direito à dignidade dos povos indígenas e pelo estudo dos diálogos contemporâneos latino-americanos que contribuíram para a elaboração de importantes cartas de direitos.

\section{A FALÁCIA DO DISCURSO DOMINANTE: O ENCOBRIMENTO E RESGATE DA AMÉRICA LATINA NA CONSTRUÇÃO DO DISCURSO DOS DIREITOS HUMANOS}

O fenômeno da modernidade carrega a pré-concepção de um desenvolvimento filosófico exclusivamente europeu, que foi desenvolvido desde a Idade Média e se difundiu por todo o mundo. A partir dessa visão, presume-se que a cultura europeia e sua racionalidade possuem características que permitem a superação ${ }^{29}$ de todas as outras culturas ${ }^{30}$. Desse modo, parte-se de uma pré-concepção que indica a existência de indivíduos com autoridade para produzir e difundir conhecimento, enquanto que, aos outros, cabe apenas o papel de mero observadores e receptadores do discurso ${ }^{31}$.

No que se refere à construção de um discurso de direitos humanos, a relação entre América Latina e Europa remete a uma experiência vivenciada no novo continente, na qual a disseminação da verdade e do conhecimento

29 "Each concept has changed over time and has been the subject of controversy. Each has sometimes acquired associations that are inappropriate here: 'civilization' has often been used in colonial contexts to suggest the superiority of Western civilization in respect of such matters as religion (Christianity), learning (science), technology, education, law (modernity) and even manners (civility). Civisisation is often contrasted with barbarism. Similarly, terms like 'culture' and 'cultured' are sometimes used narrowly, even snobbishly, to refer to 'high culture', or to 'higher' learning, the arts and literature, or manners. Conversely 'tradition' and 'traditional' sometimes carry suggestions of conservatism, inertia and resistance to change." (TWINING, William. General jurisprudence: understanding law from a global perspective. New York: Cambridge University Press, 2009. p. 78)

30 DUSSEL Enrique. Ética da libertação na idade da g/obalização e da exclusão. 3. ed. Petrópolis: Vozes, 2007. p. 52.

31 BRAGATO, Fernanda Frizzo. O papel dos estudos pós-coloniais para a ressignificação do discurso de fundamentação dos direitos humanos. In: ROCHA, Leonel Severo; CALLEGARI, André Luís; STRECK, Lenio Luiz. Constituição, sistemas sociais e hermenêutica: Anuário do Programa de Pós-Graduação em Direito da Unisinos, Mestrado e Doutorado, Porto Alegre: Livraria do Advogado, n. 8, 2011 b. p. 113. 
ocorria no mesmo fluxo em que ocorrem as trocas entre conquistadores e colonizados. Desse modo, a forma de compreender o direito na América Latina traduziu-se, durante muito tempo, como um processo de incorporação dos sistemas legais europeus, por força dos longos períodos de colonização. Assim, toda a construção jurídica ${ }^{32}$ envolvendo os direitos humanos retorna a um passado em que a cultura dominante se sobressaía sobre a cultura dos povos dominados.

Convencionalmente, o estudo da fundamentação dos direitos humanos tem partido do pressuposto no qual sua criação e seu desenvolvimento ocorrem nas lutas burguesas e nas subsequentes declarações de direitos de teor extremamente individualista ${ }^{33}$. Neste sentido, o discurso que prepondera é um discurso centrado em uma premissa ocidental que, após o devido amadurecimento, expandiu-se e incorporou-se nos demais sistemas jurídicos em desenvolvimento. A partir disso, constrói-se uma visão da Modernidade, em que a produção do conhecimento e da verdade estava centrada nas discussões ocorridas na Europa ${ }^{34}$.

Nesse sentido, o discurso dominante europeu insere, na Modernidade, a síntese dos ideais iluministas, consolidando o pensamento que justifica "o empoderamento do indivíduo através da concessão de direitos derivados do exercício de uma vontade livre e incondicionada" ${ }^{\prime 35}$. A partir desta postura, os valores e as práticas culturais de outras origens são negados, e acabam sem possuir qualquer relevância, subestimando as contribuições latino-americanas para a formação de uma teoria dos direitos humanos.

A partir do comportamento europeu que acaba por tornar as outras culturas, mundos e pessoas em objeto, encobrindo-as, ou seja, a Europa

32 "Although not explicitly stated in this example, it is commonly assumed that the standard case involves transfer from an advanced (parent) civil or common law system to a less developed one, in order to bring about technological change ("to modernise" by filling in gaps or replacing prior local law." (Twining, op. cit., p. 277)

33 Fernanda Bragato explica que "o sujeito de direitos é o indivíduo humano, ao passo que o individualismo implica, ao mesmo tempo, as ideias de liberdade e igualdade, porque a qualidade de filhos de Deus tornou os homens iguais, colocando a essência do homem por inteiro em cada um deles. Daí que qualquer afirmação da humanidade que não derive da sua própria interioridade não pode subsistir nesse sistema de significações. 0 fato de que o discurso dos direitos humanos está atrelado a esta premissa é facilmente constatável entre os teóricos dos direitos humanos" (BRAGATO, Fernanda Frizzo. Pessoa humana e direitos humanos na Constituição brasileira de 1988 a partir da perspectiva pós-colonial. Tese (Doutorado em Direito) - Programa de Pós-Graduação em Direito da Universidade do Vale do Rio dos Sinos. São Leopoldo/RS, 2009. p. 76-77).

34 BRAGATO, Fernanda Frizzo. Contribuições teóricas latino-americanas para a universalização dos direitos humanos. Revista Jurídica da Presidência, v. 13, p. 14-16, 2011 a.

35 BRAGATO, Fernanda Frizzo. Para além do individualismo: crítica à irrestrita vinculação dos direitos humanos aos pressupostos da modernidade ocidental. In: ROCHA, Leonel Severo; CALLEGARI, André Luís; STRECK, Lenio Luiz. Constituição, sistemas sociais e hermenêutica: Anuário do Programa de Pós-Graduação em Direito da Unisinos, Mestrado e Doutorado. Porto Alegre: Livraria do Advogado, n. 7, 2010. p. 105. 
projeta-se no Novo Continente, sem reconhecê-lo como outro, mas, sim, inventando-o como cópia de si mesmo ${ }^{36}$. Dessa forma, a Europa garante para si não apenas o papel principal no discurso dominante, resultado dos frutos colhidos na Idade Média e dos frutos conquistados pelo processo de expansão, conquista e dominação do continente americano, mas, também, uma vantagem substancial sobre as demais populações ${ }^{37}$. Nesse sentido, Enrique Dussel menciona que a América não aparece como outro ser com possibilidade de se autorrealizar, e sim apenas como "ser inventado à imagem e semelhança da Europa"38.

Assim, no que se refere aos direitos humanos, a lógica predominante é a lógica de produção do conhecimento eurocêntrica, cujo produto é resultado da cultura e do esforço político ocidental. No entanto, ao contrário do que defende o discurso europeu dominante, a origem não individualista dos direitos humanos retorna os debates oriundos da legitimidade da conquista das terras do continente americano pelos europeus $\mathrm{s}^{39}$ e, consequentemente, sobre o direito de submeter os povos originários à escravidão ${ }^{40}$. Desse modo, Tzvetan Todorov comenta que, "em primeiro lugar, a descoberta da América, ou melhor, a dos americanos é sem dúvida o encontro mais surpreendente de nossa história. Na 'descoberta' dos outros continentes e dos outros homens não existe, realmente, este sentimento radical de estranheza" ${ }^{\prime 4}$.

Desse modo, sem dúvida, a conquista da Américas tratou-se de acontecimento único, sem igual na história da modernidade, podendo ser classificada como um desastre humano, considerando a expulsão dos povos de suas bases territoriais, a não aceitação de sua cultura diferenciada e, também, o confisco de direitos ${ }^{42}$. Assim, Dussel traz que, a contar de 1492, a Europa se tornou o centro do mundo moderno e que sua ascensão estava umbilicalmente associada ao nascimento do ego descobridor, confrontador, controlador, vencedor e violentador do "outro". Essa é a origem do mito da

36 DUSSEL, Enrique. 1492: o encobrimento do outro - A origem do mito da modernidade. Petrópolis: Vozes, 1993. p. 35-36.

37 Idem, p. 52.

38 Idem, p. 35-36.

39 Dussel comenta que "[...] fomos a primeira 'periferia' da Europa moderna; quer dizer, sofremos globalmente desde nossa origem um processo constitutivo de modernização" (Idem, p. 16).

40 RUIZ, Castor Bartolomé. Os direitos humanos no descobrimento das América, verdades e falácias de um discurso. In: Estudos jurídicos. São Leopoldo: Unisinos, jul./dez. 2007. p. 60.

41 TODOROV, Tzvetan. A conquista da América: a questão do outro. 3. ed. São Paulo: Martins Fontes, 2003. p. 5.

42 POUMARÉDE, Jacques. Enfoque histórico do direito das minorias e dos povos autóctones. In: ROULAND, Norbert. Direito das minorias e dos povos autóctones. Brasília: Universidade de Brasília, 2004. p. 110. 
violência ${ }^{43}$, que acaba com a alteridade do descoberto, em função do encobrimento do não europeu. A relação inicial com o outro ocorreu por meio da dominação do estrangeiro absoluto pelo estrangeiro divino, que tinha como objetivo maior conquistar, matar e dominar.

Consequentemente, o primeiro contato foi caracterizado pela violência, em função do parco desenvolvimento militar dos povos indígenas em relação ao dos conquistadores. O descobrimento da América foi, desta maneira, a primeira experiência moderna onde a superioridade quase-divina do "eu" europeu impôs-se sobre o outro primitivo, rústico, inferior, "um 'eu' violento-militar que cobiça, que deseja riqueza, poder, glória" ${ }^{44}$. A conquista americana foi embasada na justificativa de que os indígenas não seriam humanos, mas, sim, seres inferiores, pertencentes quiçá a outra espécie, ou seja, antes de retirar-Ihes suas vidas, suas terras e suas liberdades, os transformaram em não humanos.

Então, a conquista representou a submissão da comunidade à escravidão e o confisco de suas terras, além de expressar atrocidades, genocídios e destruição das populações indígenas ${ }^{45}$. Em consequência a esta dominação tão cruel, algumas vozes (especialmente de missionários dominicanos e franciscanos) passaram a se manifestar, inicialmente isoladas, questionando o direito ou não do europeu de ocupar, dominar e gerir as culturas recentemente descobertas, militarmente conquistadas e em processo de colonização, conquistando os novos territórios e extraindo suas riquezas ${ }^{46}$. Assim, nas raízes do movimento contrário aos abusos cometidos na colonização estava a defesa de que os indígenas possuíam capacidade para ser autônomos, em contraposição aos que defendiam que eles eram seres inferiores, desprovidos de cultura, incapacitados e que deveriam ser tutelados ${ }^{47}$.

Como protagonistas das discussões acerca dos direitos dos indígenas em relação à dominação europeia estão, de um lado, o frei Bartolomé de Las Casas e o frei Francisco de Vitória ${ }^{48}$; e, no lado oposto, defendendo a

430 mito da modernidade traduz a ideia de que a cultua europeia é mais desenvolvida, ou seja, que a civilização é superior às outras culturas. Pelo mito da modernidade, inverte-se a realidade: "A vítima inocente é transformada em culpada, o vitimário culpado é considerado inocente" (Dussel, 1993, op. cit., p. 78-79).

44 Idem, p. 47.

45 FERREIRA, Jorge Luiz. Conquista e colonização da América Espanhola. São Paulo: Ática, 1992. p. 90.

46 Ruiz, op. cit., p. 60.

47 Bragato, 2011 a, op. cit., p. 21.

48 Quanto à contribuição de outros agentes na discussão dos direitos dos indígenas na época da colonização, Bragato expõe: "Como testemunha da colonização peruana, Poma de Ayala, índio inca do século XVII, trouxe não apenas um testemunho do desmantelamento das sociedades americanas tradicionais, mas também a formulação de ideia políticas que hoje são alguns pilares centrais do discurso dos direitos humanos (apresentou uma concepção política com limitação do poder e de respeito aos direitos dos súditos). Seus escritos são de 
dominação, Ginés de Sepúlveda. Os dois primeiros, defensores dos direitos dos indígenas, questionavam o conceito de senhorio universal do Papa (o que justificaria a colonização em função da cristianização), a legitimidade dos títulos dos reis espanhóis para dominar a América e, ainda, a situação político-jurídica dos indígenas. Já Ginés de Sepúlveda, que defendia a colonização nos moldes em que acontecia, fundamentava seu discurso no carecimento de potestade e de autoridade legítima, na legitimidade moral da submissão dos indígenas à condição de servos, visto que a causa justa da guerra é a redução à escravidão dos povos merecedores dessa sorte e que a cultura inferior dos povos indígenas os incapacita para reger a si próprios.

Bartolomé de Las Casas, frei dominicano, foi o principal teórico que argumentava a favor da humanidade dos indígenas, acabando por deslegitimar, desse modo, as bases da conquista, a escravização, as guerras e a evangelização forçada ${ }^{49}$. Um dos argumentos que fundamentava o discurso de Las Casas era o princípio da igualdade entre todos os homens, em que o grau civilizatório é irrelevante para a medida de humanidade. Afirmava também que pecado da idolatria e dos sacrifícios humanos não alterava em nada a humanidade dos indígenas. Os índios seriam súditos em potencial, não existindo argumentos que autorizassem o uso da força contra eles ${ }^{50}$. Importante ressaltar, ainda, que, para Las Casas, os homens só podem ser levados a Cristo por livre vontade e nunca por coação ${ }^{51}$. Ou seja, um frei conclui que de nada adianta obrigar os indígenas a abandonar suas crenças em nome da evangelização. Cabe mencionar a seguinte declaração de Las Casas acerca dos indígenas, em um de seus primeiros discursos contra a dominação:

E que direito e com que justiça mantendes em tão cruel e pavorosa servidão este pobres índios? Com que autoridade fizestes tão detestáveis guerras contra esta gente que estava tranquila e pacífica em suas terras, onde miríades delas, com mortes e danos nunca ouvidos, consumistes? Por acaso não são eles homens?

grande valia, pois apresenta os fatos contados sob a ótica indígena, das vítimas e foram endereçados ao Rei da Espanha, Felipe III. Sua obra 'inova o pensamento político moderno, apresentando o paradigma da coexistência como critério de legitimação para a vida política'" (BRAGATO, Fernanda Frizzo. A contribuição do pensamento de Felipe Guaman Poma de Ayala para repensar o discurso hegemônico dos direitos humanos. In: BAEZ, Narciso Leandro Xavier; CASSEL, Douglas (Org.). A realização e a proteção internacional dos direitos humanos fundamentais - Desafios do século XXI. Joaçaba: Editora Unoesc, 2011. p. 590-591).

49 Bragato, 2011 a, op. cit., p. 21.

50 Idem, p. 21.

51 WALLERSTEIN, Immanuel Maurice. O universalismo europeu: a retórica do poder. São Paulo: Boitempo, 2007. p. 38. 
Não possuem almas racionais? Ao sois, pois obrigados a amá-los como a vós mesmos ${ }^{52}$

Depois de vários anos frustrantes na luta contra a dominação indígena, Las Casas se viu no centro de um debate acadêmico no Conselho de Valladolid, na Espanha, em 1550, onde falou por cinco dias e influenciou a comissão a não aprovar o livro de Sepúlveda, cujo texto afirmava que os espanhóis tinham o dever moral de controlar os nativos. Dessa forma, a obra de Las Casa trata do reconhecimento universal da dignidade humana, abandonando gradações que inferiorizavam e interditavam direitos fundamentais para uma existência decente $\mathrm{e}^{53}$.

Bartolomé de Las Casas alcançou o ápice da consciência crítica, pois se colocou ao lado do outro, questionando que, caso a cultura europeia fosse tão mais desenvolvida, deveria mostrar isso por meio do estímulo ao desenvolvimento de outros povos, dada a sua superioridade. Deveria fazê-lo considerando a cultura do outro, respeitando sua alteridade ${ }^{54}$.

O nível de comprometimento de Las Casas com o grito de justiça do continente americano foi muito intenso, uma vez que teve sua vida e seu trabalho dedicados a esse fim. Paolo Carozza menciona que, "como a voz paradigmática do momento histórico, Las Casas conseguiu articular e defender um conjunto de ideias que, em muitos sentidos, representa o primeiro anúncio claro da linguagem moderna dos direitos humanos" ${ }^{\prime \prime 5}$.

Em defesa dos direitos de colonização estava Ginés Sepúlveda ${ }^{56}$, que escreveu tratados sobre o direito de guerra e sua legítima aplicação na conquista dos territórios americanos, defendendo a legitimidade moral da submissão dos indígenas à condição de servos. As diferenças culturais eram razão suficiente para justificar a superioridade dos europeus e seu direito de tutela sobre os indígenas. O grau de incultura dos nativos americanos incapacitava-os para regerem-se por si mesmos; logo, deveriam ser subme-

52 GALMÉS, Lorenzo. Bartolomeu de Las Casas, defensor dos direitos humanos. São Paulo: Edições Paulinas, 1991. p. 38

53 Bragato, 2011 a, op. cit., p. 21.

54 Dussel, 1993, op. cit., p. 85.

55 CAROZZA, Paolo. Esboços históricos de uma tradição latino-americana da ideia de direitos humanos. In: BAEZ, Narciso Leandro Xavier; CASSEL, Douglas (Org.). A realização e a proteção internacional dos direitos humanos fundamentais - Desafios do século XXI. Joaçaba: Editora Unoesc, 2011. p. 527.

56 Quanto aos argumentos de Sepúlveda, quatro são os principais: 1. Os ameríndios eram bárbaros, incapazes para aprender qualquer coisa, de tal tipo que se aconselha que sejam governados por outros; 2 . A dominação espanhola era a punição dos indígenas pelos seus crimes contra a lei divina e natural; 3. Os espanhóis eram, pela lei divina e natural, obrigados, a impedir o mal e as grandes calamidades ocasionados pelos sacrifícios indígenas; e 4. 0 domínio espanhol facilitava a evangelização cristã, cuidando da vida dos padres (Wallerstein, op. cit., p. 33-34). 
tidos por outros povos de um nível cultural superior ${ }^{57}$. Ainda, Sepúlveda acreditava que aos cristãos cabe a pregação do evangelho, como obrigação, existindo o direito de impô-la pelas armas: "Aos que resistem e não querem se submeter é lícito lhes aplicar a arte da caça, da qual convém usar não só contra as bestas, mas também contra aqueles homens que, tendo nascido para obedecer, recusam a servidão; tal guerra é justa por natureza" ${ }^{58}$.

A humanidade dos indígenas não era uma humanidade plena, igual à dos europeus, eles eram uma forma inferior de humanidade. E essa inferioridade estaria ancorada em suas práticas hediondas de idolatria, canibalismo e sacrifícios humanos, tornando-os bárbaros e servis, e justificando a sua submissão à evangelização forçada ${ }^{59}$. Verifica-se, pois, que o discurso da dominação fundamentou-se na verdade sobre a humanidade do indígena, uma vez que, caso não fossem considerados humanos, estaria legitimada a dominação e submissão, com as práticas abusivas e cruéis dos colonizadores, e vice-versa ${ }^{60}$. Assim, o conquistador europeu, além de ser inocente, possuía méritos, uma vez que estaria salvando vítimas inocentes, vítimas da barbárie de uma cultura inferior, que promovia a idolatria, o canibalismo e os sacrifícios humanos, promovendo um processo emancipador ${ }^{61}$.

Outro expoente na defesa indígena foi o frei Francisco de Vitória, que também contribuiu com o debate acerca da dominação, na medida em que construiu um discurso filosófico humanista (direito das gentes), com uma nova concepção de direito, por meio do princípio da autonomia dos povos, negando o direito de conquista romano e o direito medieval da potestas imperial ou papal sobre todo o orbe. São dele as primeiras formulações teóricas do direito internacional sob o princípio do respeito do outro e do intercâmbio benéfico para ambas as partes. Ainda, defendia que a universalidade e a verdade do valor da dignidade humana deveriam ser estendidas também aos povos indígenas e, assim, rebatia o argumento ressaltado por Sepúlveda no sentido de que os indígenas não seriam suficientemente inteligentes para governarem a si próprios ${ }^{62}$.

Segundo Francisco de Vitória, não era a capacidade de raciocínio que determinava os direitos, mas sim a própria existência de uma natureza humana que indicava os direitos inerentes a ela, independentes de concessão

57 Ruiz, op. cit., p. 61.

58 Sepúlveda, 1892, p. 292. Apud Ruiz, op. cit., p. 61.

59 Bragato, 2009, op. cit., p. 165.

60 Ruiz, op. cit., p. 61.

61 Dussel, 1993, op. cit., p. 78.

62 Ruiz, op. cit., p. 61-63. 
ou reconhecimento de nenhuma autoridade ou lei histórica. O seu discurso filosófico e jurídico se arquiteta em torno do conceito da dignidade da pessoa humana e tenta estender esse discurso aos indígenas, defendendo a verdade do valor universal da dignidade humana.

A partir disso, não há dúvida de que os índios tinham o poder de se autogovernar, eram donos, pública e privadamente, de seus territórios e pertences, de igual modo que os europeus. A universalidade de seu discurso não está no conteúdo de suas verdades, mas nos efeitos de poder que elas propõem ao conceito da dignidade da pessoa humana ${ }^{63}$. Nesse sentido, Castor Ruiz menciona que "o discurso dos direitos humanos tem sua origem na interpelação da alteridade das vítimas com uma finalidade estritamente política: desconstruir o discurso legitimador da dominação europeia sobre os povos indígenas" ${ }^{\prime \prime 4}$.

\section{CONTRIBUIÇÕES LATINO-AMERICANAS PARA PROMOÇÃO E PROTEÇÃO DOS DIREITOS HUMANOS NO ÂMBITO INTERNACIONAL}

As experiências de povos de países pós-coloniais são tão distintas quanto os efeitos do pós-colonialismo. Assim, pesquisar os efeitos, explorar pontos em comum e envolver-se com estórias específicas constituem abordagem mais criativa para um pesquisador do pós-colonialismo do que desenvolver generalizações ${ }^{65}$.

Para que se possa conhecer e compreender o papel relevante e inovador da América Latina na proteção dos direitos humanos, é preciso aprender a observar as contribuições periféricas ao conhecimento, bem como lembrar que a história é uma instituição que, enquanto legitima a enunciação de acontecimentos, também se mantém calada sobre outros ${ }^{66}$. A recuperação das contribuições latino-americanas para a internacionalização dos direitos humanos, rompendo com o discurso hegemônico liberal europeu, não só traz consequências positivas quanto à autoestima destes povos, mas também incentiva ao aprofundamento do conhecimento da história escondida/ esquecida, e, assim, fornece embasamento ao ensino dos direitos humanos.

63 Idem, ibidem.

64 SHARMA-BRYMER, Vinathe. Reflexões sobre pós-colonialismo e educação: tensões e dilemas de uma vivenciadora. In: COWEN, Robert; KAZAMIAS, Andreas M.; UNTERHALTER, Elaine (Org.). Educação comparada: panorama internacional e perspectivas. Brasília: Unesco, Capes, v. 2, 2012. p. 15-30.

65 Ruiz, op. cit., p. 60

66 MIGNOLO, Walter. The idea of Latin America. Oxford: Blackwell Publishing, 2008. p. 113-114. 
As primeiras nações mundiais a pensarem, idealizarem e criarem mecanismo para a proteção internacional dos direitos humanos foram as latino-americanas, demonstrando, assim, sua concepção universal acerca destes direitos ${ }^{67}$. Como principais acontecimentos históricos que embasam esse ineditismo latino-americano podem ser citados a redação da Constituição mexicana de 1917, com as primeiras previsões sobre direitos sociais; a atuação destes países para que na Carta da ONU, de 1945, fosse prevista a proteção dos direitos humanos; a elaboração da Declaração Americana dos Direitos e Deveres do Homem, da OEA, em 1948; e as importantes contribuições, bem como o apoio unânime, como bloco, com 21 países, também em 1948, para a elaboração e adoção da Declaração Universal dos Direitos Humanos, pela Assembleia Geral da ONU ${ }^{68}$.

Antes de expor mais detalhadamente as contribuições latino-americanas para a internacionalização dos direitos humanos, vale apresentar os motivos que podem justificar o esquecimento, por parte da história "oficial", destes fatos. Nesse sentido, as contribuições de Paolo Carozza são extremamente reveladoras. O autor cita como causas do obscurantismo do papel inovador latino-americano na promoção internacional dos direitos humanos, inicialmente, o fato de que, com o advento da Guerra Fria, o debate dos direitos humanos acabou sendo dominado pelo conflito ideológico entre direitos capitalistas (civis e políticos) e direitos socialistas (econômicos, sociais e culturais), e, como a cultura latina não defendia nenhum dos polos, acabou ficando à margem da história ${ }^{69}$.

Aliado a isso, Carozza associa a invisibilidade latino-americana ao descolonialismo africano e ao apartheid, que desviaram o olhar mundial para as questões raciais. De igual forma, a ascensão de governos autoritários na América Latina, que violavam os direitos humanos, restringia a liberdade de expressão e reduzia o debate sobre os direitos humanos. Além disso, o crescimento do aparato financeiro de ONGs na Europa e nos Estados Unidos, que seriam responsáveis pelo discurso internacional dos direitos humanos, também contribui para o esquecimento do papel latinoamericano $^{70}$.

\footnotetext{
67 Bragato, 2009, op. cit., p. 181.

68 Idem, p. 182.

69 CAROZZA, Paolo. From conquest to Constitutions: retrieving a Latin American tradition of the idea of human rights. Human Rights Quarterly, Baltimore/USA, v. 25, n. 2. Disponível em: <http://www.jstor.org/ stable/20069666>. Acesso em: 18 jul. 2016. 
Como um dos marcos do caráter inovador da América Latina na internacionalização dos direitos humanos, a Constituição mexicana de 1917 harmonizou como indivisíveis os direitos de cunho liberal com os de natureza social. A Constituição contemplou direitos sociais e econômicos, sem declarar a superioridade deles em relação às liberdades, antecipando, assim, com muita anterioridade, a inter-relação e interdependência entre direitos sociais e de liberdade, tendência que depois se firmou internacionalmente ${ }^{71}$. Em termos de conteúdo, foi a primeira constituição que considerou o mundo remodelado após a Primeira Guerra Mundial, incorporando garantias sociais e econômicas, além de proteções e disposições específicas acerca da reforma agrária, do trabalho e das dimensões sociais dos direitos de propriedade ${ }^{72}$.

No que se refere à elevação dos direitos trabalhistas à qualidade de direitos fundamentais, Fábio Konder Comparato salienta a importância histórica dessa contribuição, uma vez que na Europa a questão da dimensão social dos direitos humanos apenas emergiu após a Primeira Guerra Mundial $^{73}$. Dessa forma, percebe-se a influência da Carta mexicana na Constituição de Weimar, em 1919, e na redação das Convenções da Organização Internacional do Trabalho, em 1919, cujo teor alcança as matérias já abordadas na Constituição mexicana, como a limitação da jornada, a proteção da maternidade, entre outros ${ }^{74}$. Além disso, a Carta mexicana teve forte impacto na região latino-americana, reforçando a ideia de que a dignidade humana e a sociedade são a base das expressões dos direitos humanos. Conforme Carozza,

o paralelo entre as políticas sociais revolucionárias mexicanas e o ativismo social católico destaca a continuidade de um dos temas centrais da tradição latino-americana: procurar combinar e equilibrar o indivíduo e os aspectos comuns dos direitos humanos. Este é o "liberalismo social" que o México legou ao constitucionalismo em geral. ${ }^{75}$

Assim, passados 30 anos, o México levou este discurso para o âmbito internacional, auxiliando, primeiramente, em 1945, na elaboração da Carta da ONU, em 1948, na redação da Declaração Americana dos Direitos e Deveres do Homem, e, por fim, no mesmo ano, na construção da Declaração Universal dos Direitos Humanos.

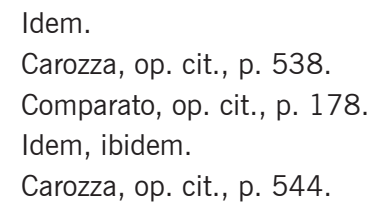


Em abril de 1945, em São Francisco ${ }^{76}$, quando delegados de 50 países se reuniram para dar os retoques em uma carta proposta às Nações Unidas, representantes da América Latina e do Caribe chegaram com um plano de trabalho, pretendendo a inclusão de uma declaração internacional de direitos. Essa ideia estava muito longe do que pretendiam as mentes dos líderes aliados que convocaram a conferência, na medida em que Churchill, Roosevelt e Stalin pretendiam um acordo de segurança coletiva para o pós-guerra. Dessa forma, os direitos humanos não estavam entre as prioridades das grandes potências, sendo mencionados apenas uma vez em sua sugestão de Carta $^{77}$. Tal fato decorre da redução dos direitos humanos aos habitantes de seus próprios territórios, ou seja, nos Estado Unidos ocorria uma severa política de segregação racial contra os negros, a União Soviética mantinham seus Gulag e a França e Inglaterra continuavam com seus impérios coloniais na África e na Ásia ${ }^{78}$.

Entre os delegados que estavam na conferência de São Francisco, vários tinham uma visão mais ampla sobre um novo modelo da organização, uma visão que incluía a proteção dos direitos humanos. Os delegados estavam bem preparados para esse papel, por experiência e em números, pois já trabalhavam na ideia de direitos humanos a nível supranacional. Já, em 1938, com a guerra iminente, a Conferência Interamericana (o antecessor da Organização dos Estados Americanos) aprovou uma "Declaração em Defesa dos Direitos Humanos" em sua oitava reunião internacional, ocorrida em Lima. A declaração afirmava que, ao "se recorrer à guerra em qualquer outra região do mundo, o respeito deve ser dado aos direitos humanos, aos sentimentos humanitários, e para a herança espiritual e material da civilização". Na mesma conferência, três resoluções prospectivas foram adotadas: uma condenando a perseguição racial e religiosa, uma em favor dos direitos das mulheres, e uma sobre a liberdade de associação para trabalhadores ${ }^{79}$.

Em 1945, antes da reunião de São Francisco, a Conferência Interamericana realizou uma reunião na Cidade do México, onde propôs a inclusão de uma declaração transnacional de direitos na ONU. A proposição não foi bem recebida pelas maiores potências mundiais da época, mas recebeu

76 Em abril de 1945, em São Francisco, nos EUA, ocorreu a conferência, com a presença de 51 países, que resultou na criação da Organização das Nações Unidas.

77 GLENDON, Mary Ann. The Forgotten Crucible: The Latin American influence on the universal human rights idea. Harvard Human Rights Journal, v. 16, p. 27-28, 2003. Disponível em: <http://law.harvard.edu/ students/orgs/hrj/iss16/ glendon.pdf>. Acesso em: 12 jul. 2016.

78 ISA, Felipe Gómez. La Declaración Universal de Derechos Humanos: algunas reflexiones en torno a su génesis y a su contenido. In: La Declaración Universal de Derechos Humanos em su cincuenta aniversario. Bilbao: Universidad de Deusto, 1999. p. 28.

Idem, p. 29. 
importante apoio da opinião pública, sendo, então, adotada por meio da previsão do compromisso da ONU com a proteção dos direitos humanos constante na Carta e com a previsão de criação de uma Comissão de Direitos Humanos ${ }^{80}$.

Ainda, na reunião em São Francisco, logo em seu início, o Panamá apresentou um projeto de declaração dos direitos humanos. Delegados do Chile, de Cuba e do México uniram-se ao Panamá para travar uma luta sem sucesso para ter essa declaração incorporada na Carta das Nações Unidas. A ideia original, especialmente do Panamá e do México, era que ocorresse a inclusão de uma declaração de direitos na Carta da ONU. Todavia, foram as propostas menos audaciosas de Cuba e Uruguai que venceram, condicionadas à elaboração de uma Declaração Universal de Direitos Humanos logo após a formação da ONU ${ }^{81}$.

Em função do empenho da delegação latino-americana que formava o maior bloco (21 dos 51 Estados), em um período no qual ainda vigorava o colonialismo, foi incluída a preocupação com os direitos humanos na Carta da $\mathrm{ONU}^{82}$. Como resultado da campanha dos países latino-americanos, a Carta foi redigida trazendo referências aos direitos humanos, com afirmações sobre igualdade e direitos humanos já em seu preâmbulo, bem como uma declaração sobre a promoção e o respeito aos direitos humanos como um dos propósitos básicos da organização ${ }^{83}$.

Conforme Isa, a inclusão das disposições de direitos humanos na Carta das Nações Unidas alterou os parâmetros do debate sobre os direitos humanos e introduziu novos princípios na política mundial e no direito internaciona ${ }^{84}$. Assim, após a instalação e o início do funcionamento da $\mathrm{ONU}$, os delegados latino-americanos seguiram ativos na luta pelos direitos humanos, pois uma das primeiras tarefas da nova organização à Comissão de Direitos Humanos foi a preparação de uma "carta internacional de direitos" ${ }^{\prime 85}$. Desse modo, tiveram início os trabalhos que resultaram na Declaração Universal dos Direitos Humanos ${ }^{86}$. O texto elaborado pela comis-

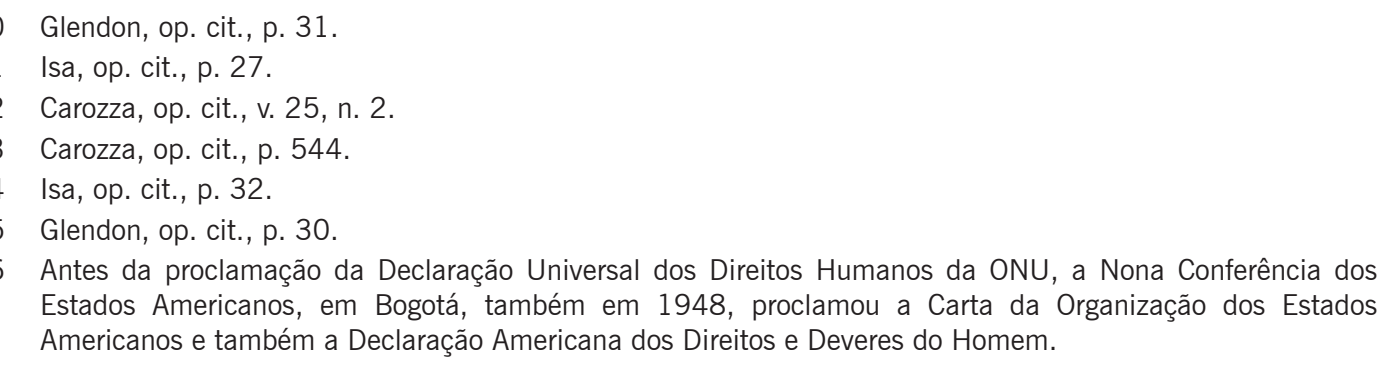


são teve como principal contribuição a proposta do Panamá, já apresentada em São Francisco ${ }^{87}$.

Apesar da elaborada redação da Carta da OEA, como, por exemplo, o art. 5, que declara que a "Os Estados Americanos proclamam os direitos fundamentais dos indivíduos sem distinção de raça, nacionalidade, credo ou sexo", a Carta falha ao não definir os direitos mencionados e tampouco estabelecer os mecanismos para sua implementação. De igual forma, a Declaração, ao elencar os direitos, definiu que "a proteção internacional dos direitos do homem deve ser o principal guia para a evolução do direito americano", porém tampouco instituiu mecanismos de garantia. Assim, o principal obstáculo à efetivação da Declaração da ONU era o entendimento de que as declarações careciam de força legal para criar obrigações para os Estados ${ }^{88}$.

Uma vez aprovada, é possível identificar que as contribuições da América Latina ${ }^{89}$ na Declaração Universal estavam entre os principais fatores que ajudaram a evitar os extremos do individualismo ou do coletivismo, permitindo que ela se tornasse o principal modelo para a maioria dos instrumentos de direitos no mundo de hoje. Nem o estilo norte-americano nem um documento de estilo soviético poderiam ter levado a um consenso a partir de uma ONU que incluiu representantes de tantas culturas diferentes ${ }^{90}$.

Cabe ressaltar que o principal aporte para a elaboração da Declaração Universal dos Direitos Humanos da ONU de 1948 foi o projeto proposto pelo Panamá em 1945. Entre as contribuições importantes dos demais países latino-americanos podem ser destacadas as seguintes participações: direitos iguais para homens e mulheres no preâmbulo do documento (igual-

87 Bragato, 2009, op. cit., p. 184.

88 Idem, p. 185.

89 A importância das contribuições da América Latina foi reconhecida oficialmente em 9 de dezembro de 1948, quando Charles Malik, relator da Comissão da ONU de Direitos Humanos, apresentou o projeto de Declaração Universal dos Direitos Humanos à Assembleia Geral para votar. Malik começou por descrever o documento como um marco na história: uma síntese de todas as tradições existentes direitos. Após observar que um grande número de propostas de uma declaração internacional de direitos tinha sido enviado de todo o mundo, ele destacou os projetos do Panamá, do Chile e de Cuba para uma menção especial. Ele reconheceu Hernán Santa Cruz por ter "mantido vivo em nossa mente a perspectiva grande de seu mundo humano da América Latina", "Mr. Cisneros de Cuba e Carrera Mário de Andrade do Equador [que] têm contribuído desde o grande fundo de sua erudição e alto idealismo", "a lógica afiada legal do Sr. De Aréchaga do Uruguai", e observou que "crédito deve ir para o movimento de Minerva Bernardino, da República Dominicana" para a menção da igualdade de direitos entre homens e mulheres no preâmbulo. Por insistência de Pérez Cisneros, de Cuba, a referência à necessidade das famílias foi inserida no que seria 0 art. 23 , sobre direito à justa remuneração. Em função do equador, o art. $9^{\circ}$ foi alterado para incluir proteção contra o exílio voluntário. E ainda, a pedido do México, um novo artigo - que se tornaria o $8^{\circ}$, foi adicionado, adotando a instituição latino-americana conhecida como amparo (direito a um recurso efetivo para os atos de violação dos direitos fundamentais) (Glendon, op. cit., p. 38-39).

Idem, p. 39. 
dade de gênero), proposto pela República Dominicana; necessidades das famílias (direito a um padrão de vida adequado, art. XXIII) e proteção da maternidade, proposto por Cuba; previsão do Recurso de Amparo (remédio processual para tribunais nacionais devido às violações aos direitos) presente no art. VIII e, também, "nenhuma limitação de raça, nacionalidade ou religião, relativo ao direito de casar e constituir família" (art. XVI) e proteção da maternidade, propostos pelo México; reconhecimento dos direitos das pessoas que não podem prever suas próprias necessidades, proposto pelo Chile; e as contribuições acerca dos direitos das crianças, propostas por Venezuela e Argentina ${ }^{91}$.

Bragato chama a atenção para um fato tornado "invisível" pela história, mas que demonstra o papel precursor das nações latino-americanas na internacionalização dos direitos humanos, que é o primeiro artigo da Declaração Universal, cuja redação é reprodução fiel da Declaração Americana dos Direitos e Deveres do Homem da OEA, que declara: "Todos os homens nascem livres e iguais em dignidade direitos e, como são dotados pela natureza de razão e consciência, devem proceder fraternalmente uns para com os outros" ${ }^{\prime 92}$. Nesse sentido, Carozza reafirma o papel da delegação latino-americana na elaboração da Declaração Universal, uma vez que

houve, de fato, um fortíssimo e distinto compromisso latino-americano com a ideia de direitos humanos em 1948. Primeiro, a região mostrou uma dedicação aos direitos humanos internacionais num tempo em que, geralmente, a ideia ainda era vista com relutância ou mesmo com hostilidade pela maioria dos Estados. As vozes latino-americanas ressoaram com a firme crença na universalidade dos direitos e, especialmente, na igualdade de direitos entre raças e ambos os sexos. Seus entendimentos acerca dos direitos enfatizavam a dimensão social da pessoa humana, desde a família às estruturas sociais e econômicas nas quais ela realiza a sua dignidade. E mesmo enquanto defendiam os direitos, eles também procuraram equilibrá-los com a linguagem dos deveres. ${ }^{93}$

Desse modo, é possível reconhecer o importantíssimo papel que as nações latino-americanas tiveram ao longo da história não apenas para a composição de um novo discurso dos direitos humanos (contrário ao hegemônico europeu), mas também para a internacionalização desses direitos. As contribuições latino-americanas para o surgimento formal do direito internacional dos direitos humanos, em 1948, são reflexo da tradição longa e profunda da ideia de direitos humanos nesses países, ideia esta tão antiga

91 Idem, p. 38-39.

92 Bragato, 2010, op. cit., p. 119.

93 Carozza, op. cit., v. 25, n. 2; Carozza, op. cit., p. 524. 
quanto o encontro turbulento entre a Europa e o Novo Continente. A tradição latino-americana pode, ainda, ser caracterizada por "sua capacidade de se apropriar, adaptar e transformar os ideais que recebeu no campo da experiência e prática" ${ }^{\prime 94}$.

Assim, resta clara e reconhecida, infelizmente, por apenas alguns historiadores e conhecedores do tema, a influência latino-americana na elaboração da Declaração Universal dos Direitos Humanos, em 1948. Dessa forma, não é de se estranhar o fato de que essa informação não seja ensinada em nossas escolas de formação jurídica, pois, mesmo com a existência de políticas públicas, essas falham ao não mencionar a retomada de tais acontecimentos.

Cabe uma reflexão sobre a seguinte constatação de Edgar Morin:

[...] um conhecimento não é mais pertinente porque contém um número maior de informações, ou porque é organizado da forma mais rigorosa possível sob uma forma matemática; ele é pertinente se souber situar-se em seu contexto e, mais além, no conjunto no qual está vinculado. [...] O conhecimento abstrato é necessário, mas fica mutilado se não for acompanhado de conhecimentos concretos. [...] Enfim, o conhecimento do conhecimento exige que se pratique sem cessar a reflexividade, ou seja, o autoexame, que, eventualmente, inclui a autocrítica, um modo de pensar o pensamento que implica, igualmente, pensar nas condições históricas, culturais e sociais da própria existência. ${ }^{95}$

Aqui se tem algumas chaves para o reposicionamento do tema dos direitos humanos na formação jurídica. A excessiva preocupação com a teoria, com a concepção jurídica abstrata, descontextualizada de problemas reais e pertinentes à realidade social, econômica e política brasileira faz com que a educação jurídica forme bacharéis sem condições de vislumbrar soluções jurídicas inovadoras e flexíveis. Isso gera um déficit de profissionais que tenham condições de se adaptar às mudanças legislativas e orientar soluções para problemas concretos, apesar da carga teórica recebida. No entanto, como esta carga teórica é desconectada dos caminhos para a sua aplicação na resolução de problemas concretos, se terá cada vez mais trabalhadores jurídicos incapazes de dar conta dos desafios sociais complexos e com características inéditas. Aí o seio da crise do ensino e da educação jurídicos que está a exigir um enfrentamento sério e comprometido.

94 Idem.

95 MORIN, Edgar. A via para o futuro da humanidade. Trad. Edgard de Assis Carvalho e Mariza Perassi Bosco. Rio de Janeiro: Bertrand Brasil, 2013. p. 191-193. 


\section{CONSIDERAÇ̃EES FINAIS}

O resgate das contribuições latino-americanas para a construção de um discurso dos direitos humanos diferente do hegemônico europeu é um fator que influencia diretamente a construção do interesse acadêmico neste estudo. A educação, já mencionada na própria Declaração Universal dos Direitos Humanos, em seu preâmbulo e no art. 26, é vital para a compreensão, divulgação e conscientização dos direitos humanos, permitindo, assim, a formação de cidadãos conscientes, aptos a lidarem com os desafios da realidade.

Apesar da existência de um Plano Nacional de Ensino de Direitos Humanos (PNEDH), ele contempla muito poucas ações em relação às Instituições de Ensino Superior, e em nada modifica as diretrizes curriculares que definem as disciplinas a serem oferecidas pelos cursos de direito do País. Ao considerarmos a não obrigatoriedade da existência de uma disciplina voltada especificamente ao ensino dos direitos humanos nos cursos jurídicos brasileiros, a dificuldade dos docentes trabalharem transversalmente o tema, em diferentes disciplinas, e a postura negativa que a maioria dos acadêmicos de direito tem quanto ao assunto (por falta de conhecimento), aliados ao desconhecimento do importante papel precursor que as nações latino-americanas possuem quanto à promoção, proteção e internacionalização dos direitos humanos, percebe-se que o atual quadro de desinformação desses acadêmicos tem fortes justificativas.

Desse modo, inúmeros operadores do Direito podem ser considerados como aculturados em relação aos direitos humanos, como reflexo de uma formação positivista e normativista falha que segue existindo em nossas escolas, desconsiderando a realidade e a longa tradição latino-americana quanto aos direitos humanos. Acredita-se que a promoção dos direitos humanos passa pelo resgate não apenas das contribuições contemporâneas dos países latino-americanos para a promoção e proteção dos direitos humanos, mas também é extremamente importante ir além, retornando no tempo e na história (esquecida) até a colonização, buscando, assim, os debates entre Las Casas e Sepúlveda sobre a manutenção da dignidade indígena.

A questão não é apenas desconsiderar o discurso eurocêntrico, mas, sim, resgatar a tradição obscurecida e esquecida latino-americana na reformulação dos conceitos ideias e fundamentos dos direitos humanos. Dessa forma, espera-se que pensadores e governantes latino-americanos resgatem seu patrimônio histórico e cultural, "em sua plenitude, não só por causa de 
suas próprias experiências democráticas, mas por causa do movimento de direitos humanos" ${ }^{\prime \prime 6}$.

As discussões promovidas no passado, associadas às construções realizadas no futuro, colaboram para redesenhar o papel da América Latina na fundamentação dos direitos humanos. Os países do Novo Continente que experimentaram os efeitos do passado colonial, ao contrario do que é ensinado, são muito mais do que meros coadjuvantes, são verdadeiros atores na construção de um discurso não individualista de direitos humanos, apresentando verdadeiros fundamentos que justifiquem o porquê de lutar por uma causa tão desvalorizada. Desse modo, resgatar o passado e corrigir o presente são indicadores para a construção de um caminho que leve os direitos humanos a sério.

\section{REFERENNCIAS}

ALVES, José Augusto Lindgren. Os direitos humanos como tema global. 2. ed. São Paulo: Perspectiva, 2003.

BRAGATO, Fernanda Frizzo. A contribuição do pensamento de Felipe Guaman Poma de Ayala para repensar o discurso hegemônico dos direitos humanos. In: BAEZ, Narciso Leandro Xavier; CASSEL, Douglas (Org.). A realização e a proteção internacional dos direitos humanos fundamentais - Desafios do século XXI. Joaçaba: Editora Unoesc, 2011.

. Para além do individualismo: crítica à irrestrita vinculação dos direitos humanos aos pressupostos da modernidade ocidental. In: ROCHA, Leonel Severo; CALLEGARI, André Luís; STRECK, Lenio Luiz. Constituição, sistemas sociais e hermenêutica: Anuário do Programa de Pós-Graduação em Direito da Unisinos, Mestrado e Doutorado. Porto Alegre: Livraria do Advogado, n. 7, 2010.

. Contribuições teóricas latino-americanas para a universalização dos direitos humanos. Revista Jurídica da Presidência, v. 13, 2011 a.

- O papel dos estudos pós-coloniais para a ressignificação do discurso de fundamentação dos direitos humanos. In: ROCHA, Leonel Severo; CALLEGARI, André Luís; STRECK, Lenio Luiz. Constituição, sistemas sociais e hermenêutica: Anuário do Programa de Pós-Graduação em Direito da Unisinos, Mestrado e Doutorado. Porto Alegre: Livraria do Advogado, n. 8, 2011 b.

. Pessoa humana e direitos humanos na Constituição brasileira de 1988 a partir da perspectiva pós-colonial. Tese (Doutorado em Direito) - Programa de 
Pós-Graduação em Direito da Universidade do Vale do Rio dos Sinos. São Leopoldo/RS, 2009. $267 \mathrm{f}$.

BRASIL. Diretrizes Curriculares Nacionais para o Curso de Graduação em Direito. Disponível em: <http://portal.mec.gov.br/cne/arquivos/pdf/rces09_04.pdf>. Acesso em: 10 jul. 2016.

Plano Nacional de Educação em Direitos Humanos: 2007, Comitê Nacional de Educação em Direitos Humanos. Brasília: Secretaria Especial de Direitos Humanos, Ministério da Educação, Ministério da Justiça, Unesco, 2006. Disponível em: <http://portal.mj.gov.br/sedh/edh/pnedhpor.pdf>. Acesso em: 10 jul. 2016. PNDH-3 reúne políticas sobre direitos humanos. Disponível em: <http:// www.brasil.gov.br/cidadania-e-justica/2012/04/PNDH-3-reune-politicas-sobre-direitos-humanos>. Acesso em: 10 jul. 2016.

. Resolução CNE/CES no 9, de 29 de setembro de 2004. Disponível em: <http://portal.mec.gov.br/cne/arquivos/pdf/rces09_04.pdf>. Acesso em: 10 jul. 2016.

CARBONARI, P. C. Sujeito de direitos humanos: questões abertas e em construção. In: SILVEIRA, Rosa Maria Godoy et al. (Org.). Educação em direitos humanos: fundamentos teórico-metodológicos. 1. ed. João Pessoa: UFPB, 2007.

CAROZZA, Paolo. Esboços históricos de uma tradição latino-americana da ideia de direitos humanos. In: BAEZ, Narciso Leandro Xavier; CASSEL, Douglas (Org.). A realização e a proteção internacional dos direitos humanos fundamentais - Desafios do século XXI. Joaçaba: Editora Unoesc, 2011. p. 521-545.

. From conquest to Constitutions: retrieving a Latin American tradition of the idea of human rights. Human Rights Quarterly, Baltimore/USA, v. 25, n. 2. Disponível em: <http://www.jstor.org/stable/20069666>. Acesso em: 18 jul. 2016.

COMPARATO, Fábio Konder. A afirmação histórica dos direitos humanos. 5. ed. rev. e atual. São Paulo: Saraiva, 2007.

COSTA, Bárbara Silva. A (in)suficiência do paradigma dogmático no modo de observar e ensinar o direito. Dissertação (Mestrado em Direito) - Programa de Pós-Graduação em Direito da Universidade do Vale do Rio dos Sinos. São Leopoldo/ RS, 2007. $232 \mathrm{f}$.

DUSSEL, Enrique. 1492: o encobrimento do outro - A origem do mito da modernidade. Petrópolis: Vozes, 1993.

Ética da libertação na idade da globalização e da exclusão. 3. ed.

Petrópolis: Vozes, 2007.

ESQUIROL, Jorge L. The fictions of Latin American law. Utah Law Review, Salt Lake City/USA, 425, 1997. 
FERRAZ, Anna Cândida da Cunha. Educação em direitos humanos: pressuposto para o exercício da cidadania. In: SILVEIRA, Vladimir Oliveira da; SANCHES, Samyra Haydêe Dal Farra Naspolini; COUTO, Mônica Bonetti (Org.). Educação jurídica. São Paulo: Saraiva, 2013.

FERREIRA, Jorge Luiz. Conquista e colonização da América espanhola. São Paulo: Ática, 1992.

FLORES, Joaquim Herrera. A (re)invenção dos direitos humanos. Trad. Carlos Roberto Diogo Garcia, Antonio Henrique Graciano Suxberger e Jefferson Aparecido Dias. Florianópolis: Fundação Boiteux, 2009.

FREITAS, Ana Teresa Silva de. Ensino e legitimação dos direitos humanos. In: GONÇALVES, Claudia Maria da Costa (Coord.). Direitos humanos - Vozes e silêncio. Curitiba: Juruá, 2011.

GALMÉS, Lorenzo. Bartolomeu de Las Casas, defensor dos direitos humanos. São Paulo: Edições Paulinas, 1991.

GLENDON, Mary Ann. The Forgotten Crucible: the Latin American influence on the universal human rights idea. Harvard Human Rights Journal, v. 16, 2003. Disponível em: <http://law.harvard.edu/students/orgs/hrj/iss16/glendon.pdf>. Acesso em: 12 jul. 2016.

ISA, Felipe Gómez. La Declaración Universal de Derechos Humanos: algunas reflexiones en torno a su génesis y a su contenido. In: La Declaración Universal de Derechos Humanos em su cincuenta aniversario. Bilbao: Universidad de Deusto, 1999.

LEVY, Wilson. A emergência da pedagogia do novo e de uma teoria emancipatória do ensino do direito. In: NALINI, José Renato; CARLINBI, Angélica (Coord.). Direitos humanos e formação jurídica. Rio de Janeiro: Forense, 2010.

MACEDO, Elaine Harzheim; MACEDO, Fernanda dos Santos. O ensino jurídico no sistema globalizado: repensando a educação e a pesquisa. XXI Encontro Nacional do Conpedi, Uberlândia, 2012. Disponível em: <http://www.publicadireito.com. br/artigos/?cod=feab05aa91085b7a>. Acesso em: 10 jul. 2016.

MARQUES NETO, Agostinho Ramalho. Introdução ao estudo do direito: conceito, objeto, método. 2. ed. Rio de Janeiro: Forense, 2001.

MIGNOLO, Walter. The idea of Latin America. Oxford: Blackwell Publishing, 2008.

MORAIS, José Luís Bolzan de; VIEIRA, Gustavo Oliveira. A necessidade da voz da sociedade civil organizada na concretização dos direitos humanos. In: GONÇALVES, Claudia Maria da Costa (Coord.). Direitos humanos - Vozes e silêncio. Curitiba: Juruá, 2011. p. 65-81. 
MORIN, Edgar. Os sete saberes necessários à educação do futuro. 8. ed. Trad. Catarina Eleonora F. da Silva e Jeanne Sawaya. São Paulo: Cortez; Brasília/DF: Unesco, 2003.

A via para o futuro da humanidade. Trad. Edgard de Assis Carvalho e Mariza Perassi Bosco. Rio de Janeiro: Bertrand Brasil, 2013.

NALINI, José Renato. Apresentação. In: NALINI, José Renato Nalini; CARLINI, Angélica (Coord.). Direitos humanos e formação jurídica. Rio de Janeiro: Forense, 2010.

POUMARÉDE, Jacques. Enfoque histórico do direito das minorias e dos povos autóctones. In: ROULAND, Norbert. Direito das minorias e dos povos autóctones. Brasília: Universidade de Brasília, 2004.

RUIZ, Castor Bartolomé. Os direitos humanos no descobrimento das América, verdades e falácias de um discurso. In: Estudos jurídicos. São Leopoldo: Unisinos, jul./dez. 2007.

SANTOS, Boaventura de Sousa. Para uma revolução democrática da justiça. 2. ed. São Paulo: Cortez, v. 134, 2008.

SENA, Jaqueline Santa Brígida. Ética da alteridade e direitos humanos: uma discussão necessária à formação jurídica contemporânea. In: NALINI, José Renato; CARLINBI, Angélica (Coord.). Direitos humanos e formação jurídica. Rio de Janeiro: Forense, 2010.

SHARMA-BRYMER, Vinathe. Reflexões sobre pós-colonialismo e educação: tensões e dilemas de uma vivenciadora. In: COWEN, Robert; KAZAMIAS, Andreas M.; UNTERHALTER, Elaine (Org.). Educação comparada: panorama internacional e perspectivas. Brasília: Unesco, Capes, v. 2, 2012. p. 15-30.

TODOROV, Tzvetan. A conquista da América: a questão do outro. 3. ed. São Paulo: Martins Fontes, 2003.

TWINING, William. General jurisprudence: understanding law from a global perspective. New York: Cambridge University Press, 2009.

WALLERSTEIN, Immanuel Maurice. O universalismo europeu: a retórica do poder. São Paulo: Boitempo, 2007.

WARAT, Luis Alberto. Direitos humanos: subjetividade e práticas pedagógicas. In: SOUSA JÚNIOR, José Geraldo et al. (Org.). Educando para os direitos humanos: pautas pedagógicas para a cidadania na universidade. Porto Alegre: Síntese, 2004. 